\title{
An Investigation into Outbreak of Malaria in Bareilly District of Uttar Pradesh, India
}

\author{
SKamal', Ramesh Chandra ${ }^{2}$ KK Mittra ${ }^{3}$, SN Sharma ${ }^{4}$ \\ ${ }^{1,2,3}$ Regional Office of Health \& Family Welfare, Govt. of India, Kendriya Bhawan, $9^{\text {th }}$ Floor, Aliganj, Lucknow, (U.P.), India. \\ ${ }^{4}$ National Centre for Disease Control, MOH \& FW, Govt. of India, 22, Sham Nath Marg, Delhi, India. \\ DOI: https://doi.org/10.24321/0019.5138.202034
}

I $\quad \begin{array}{lllll}\mathbf{N} & \mathbf{F} & \mathbf{O}\end{array}$

\author{
Corresponding Author: \\ S Kamal, Regional Office of Health \& Family \\ Welfare, Govt. of India, Kendriya Bhawan, $9^{\text {th }}$ \\ Floor, Aliganj, Lucknow, (U.P.), India. \\ E-mail Id: \\ shaukatkamal25@yahoo.in \\ Orcid Id: \\ https://orcid.org/0000-0002-3358-1572 \\ How to cite this article: \\ Kamal S, Chandra R, Mittra KK, Sharma SN. An \\ Investigation into Outbreak of Malaria in Bareilly \\ District of Uttar Pradesh, India. J Commun Dis \\ 2020; 52(4): 1-11. \\ Date of Submission: 2020-09-11 \\ Date of Acceptance: 2020-12-09
}

\section{$\begin{array}{lllllllllllll}\mathbf{A} & \mathbf{B} & \mathbf{S} & \mathbf{T} & \mathbf{R} & \mathbf{A} & \mathbf{C} & \mathbf{T}\end{array}$}

Uttar Pradesh is the largest state of India and is comprised of 75 revenue districts. It has vast area of $243,286 \mathrm{~km}^{2}$ and 230 million population (199.81 million as per 2011 census) with population density of 828 persons per $\mathrm{km}^{2}$. The topographical \& environmental conditions including availability of rich irrigation facilities provide congenial conditions for development of different vectors transmitting various diseases. All the six Vector Borne Diseases (VBD) namely malaria, dengue, Chikungunya, Japanese Encephalitis (JE), Kala-azar \& Lymphatic filariasis are prevalent in Uttar Pradesh and are now modifiable in the state since 2016. Among these, malaria, JE, dengue etc. are epidemic prone and claim lives during outbreak, if remained unattended in light of the NVBDCP operational guidelines. During July/ August, 2018, district Bareilly experienced outbreak of malaria, which claimed several lives according to various reports appeared in the media. A team of Officers from Regional Office for Health \& Family Welfare (ROH \& FW), Lucknow visited Bareilly district of UP during September, 2018 to assess the various factors responsible for the present outbreak and to guide $\&$ support the district health authorities for proper implementation of the various intervention measures to contain the outbreak. The detailed investigations revealed that the reasons for outbreak may be assigned to the excessive rainfall in the district, poor surveillance due to inadequate number of peripheral health workers, lack of laboratory facilities and improper monitoring \& lack of timely actions. The screening of people for malaria with bivalent antigen based RDT kits reflected high malaria positivity both Plasmodium vivax (P.v.) \& Plasmodium falciparum (P.f.) incidence but no fever related death was confirmed due to malaria.

Keywords: Malaria outbreak, Plasmodium vivax, Plasmodium falciparum, RDT Kits, Slide Positivity Rate, Annual Parasite Incidence

\section{Introduction}

Uttar Pradesh is the largest state of India and is comprised of 75 revenue districts. It has vast area of $243,286 \mathrm{~km}^{2}$ and 230 million population (199.81 million as per 2011 census) with population density of 828 persons per $\mathrm{km} .^{2}$ About two third population resides in rural areas and mainly depend on agricultural practices as the Indo - Gangetic plain is contributing a lot in the fertile agricultural region for the development of not only the state but India as 
a whole. Since this area is traversed be a number of big \& small rivers, provide good opportunity \& facility for irrigation of the crop fields. The co-lateral outcome of the irrigation facility led to the public health problem as every third person suffered due to malaria with high mortality \& morbidity prior to the independence. The National Malaria Control Programme (NMCP) was launched in 1953 with organized control efforts by performing Indoor Insecticidal Spray (IRS) inside the human dwellings with the help of only introduced insecticide DDT 50\% wdp. This IRS tool success led to implement National Malaria Eradication Programme (NMEP) in 1958 by bringing the malaria incidence to 0.10 million in 1965 , thereby eradicated the dreadful disease from almost major parts of India. The malaria free areas were handed over to the basic health services for maintaining the malaria free status in the area but the expectation reversed due to occurrence of local \& focal outbreaks of malaria with high morbidity \& mortality, thereby increasing the toll of malaria cases to 6.47 million in 1977. Thus, in order to overcome the resurgence of malaria cases, Modified Plan of Operation (MPO) was launched in 1977, the successful implementation of which brought down the malaria cases between 2-3 million but large scale malaria epidemics occurred again in 1994 in different parts of India, ${ }^{2}$ led technical officers to think over this issue seriously. Various technical, operational, financial $\&$ administrative issues were experienced to contribute the resurgence of malaria. ${ }^{3}$ In order to ensure effective implementation of the programme, National Vector Borne Disease Control Programme (erstwhile National Malaria Eradication Programme) on the basis of recommendations of group of experts, formulated the operational guidelines for malaria action programme in the country in 1995 and $^{1}$ Moreover, the process indicators were developed, which gave the details of various processes to be carried out at each level from primary health care to the top most level as well as assessment parameters to evaluate whether the implementation is going in right track or not, ${ }^{3}$ when the disease has been planned for elimination from the country. 7,8

Even with the availability of the strong implementing technical guidelines, outbreaks of malaria are still occurring in various parts of the country as well as state. District Bareilly (28.3670 $\left.\mathrm{N}, 79.4304^{\circ} \mathrm{E}\right)$ reported high pyrexia and causalities through various media reports. The present paper reflects the efforts made to (a) Investigate the cause of the unprecedented incidence, (b) Suggest the appropriate intervention measures to contain the epidemic, and (c) indicate the correctional actions \& necessary steps for future program implementation in more effective way in the district.

\section{Methodology}

In order to find out the facts and the ground realities of the incidence, the office of the Chief Medical Officer, District Malaria (VBD) Officer, District Hospital, Bareilly, District Surveillance Unit (IDSP), CHC - Majhgawan (28.3051을 $\left.\mathrm{N}, 79.2761^{\circ} \mathrm{E}\right), \mathrm{CHC}$-Bhamora (28.2090N,79.2983으) \& CHC - Faridpur (28.2091ㅇ N, 79.5378으), and two worst affected villages - Dhakora under CHC-Majhgawan and village - Sendhi under $\mathrm{CHC}$ - Bhamora were visited to find out of the operational aspects of various activities including vector prevalence and control measures in the field areas of Bareilly district of Uttar Pradesh (Figure 1).

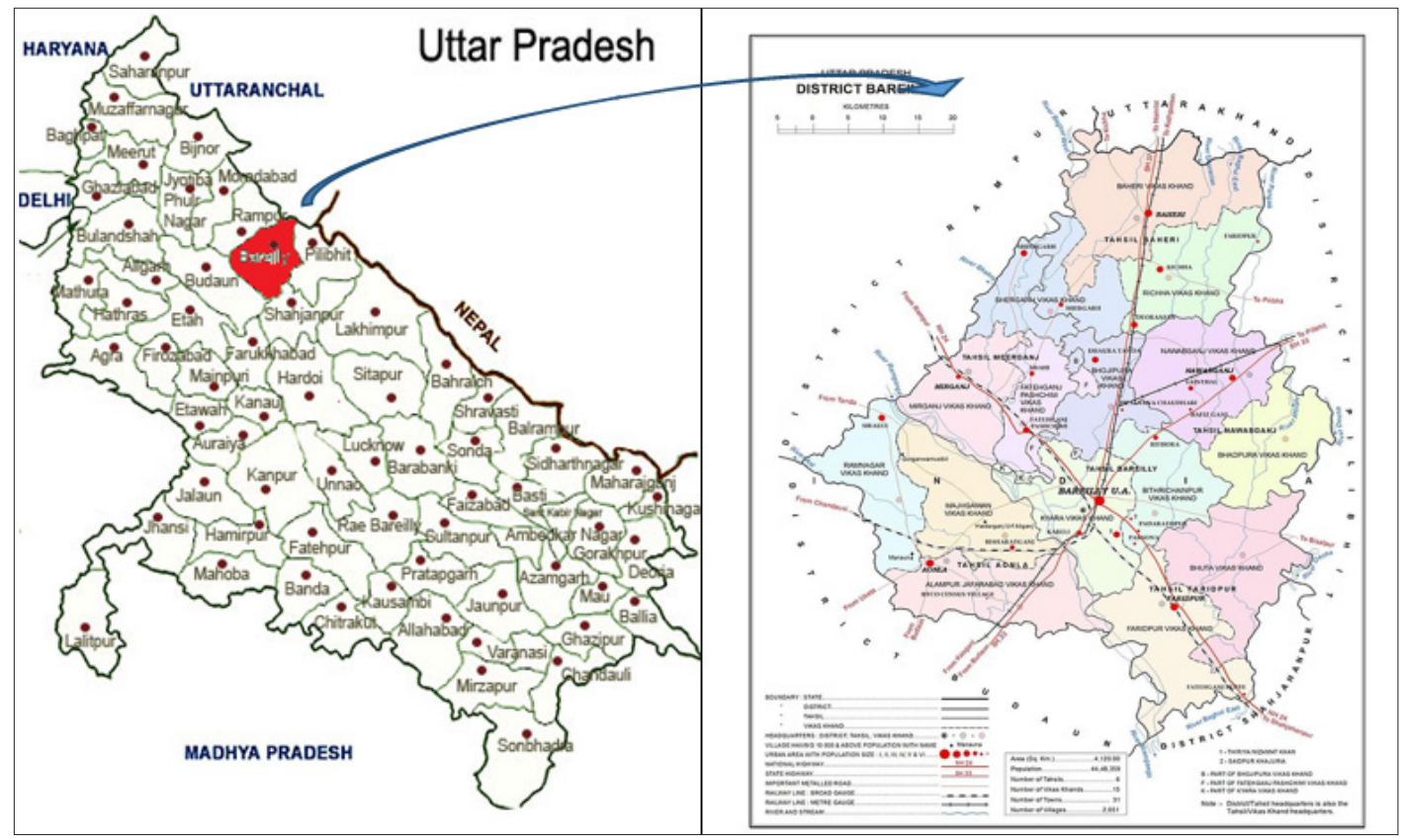

Figure I.Map of District- Bareilly, Uttar Pradesh, India 
The office of District Malaria Officer/ VBD Officer was visited to find out and analyze the old record pertaining to malaria epidemiological situation of the district during past three years, the staff availability for implementing Vector Borne Disease Control Programme, the availability of logistic/ infra-structure in the district, the details of intervention measures undertaken by the district so far, the details of fever outbreak in the district \& reasons of the same. The information on the details of deaths occurred in the district \& death audit done by the authorities of PHCs, if the death considered due to malaria on prescribed format of National Vector Borne Disease Control Programme (NVBDCP) of Government of India \& the vector prevalence in area and its role in the present outbreak was also gathered. The malaria epidemiological reports for the last three years, human resource details, intervention measures details were obtained from the District Malaria (VBD) office, Bareilly, Some other reports were obtained from CHC-Majhgawan, Bhamora \& Faridpur and IDSP Unit Bareilly. Entomological surveillance was undertaken in village - Dhakora under $\mathrm{CHC}$ -Majhgawan and village - Sendhi under CHC-Bhamora. The data obtained were analyzed and findings are presented in this communication.

\section{Result and Discussion}

The details of the fever affected CHCs/PHCs depicting malaria incidence are reflected in Figure 2A, 2B \& 3A, 3B. It is evident from the figures that the most malaria affected areas were CHC-Majhgawan, Aonla, Faridpur \& Bhamora, as they contributed $75 \%$ of malaria positives by RDT kit, CHC Majhgawan contributed highest (38.22\%), followed by CHC - Bhamora (18.67\%), Aonla (9.57\%) \& CHC-Faridpur (7.31\%), of total malaria positives, whereas, Majhgawan, Aonla, \& Bhamora contributed $87 \%$ of Plasmodium falciparum, malaria positives, Majhgawan was highest contributor (59.90\%) followed by Bhamora (18.18\%) \& Aonla (9.14\%).

The CHC-Majhgawan, which has reported the highest number of fever cases was visited. The area of Majhgawan $\mathrm{CHC}$ is located on banks of river Ramganga and reflected increased fever incidence, having no positivity for malaria in reports communicated from the CHC-Majhgawan laboratory, though the persons reflected clinical symptoms of malaria. This $\mathrm{CHC}$ has 239000 (approx.) population residing in 147 villages, out of which 122 villages (approx. 200000 population) were under the grip of fever. The $\mathrm{CHC}$ has 29 deaths related to fever, of which first death occurred in Village - Ballai on 30th August, 2018 \& last death occurred village Dhamora on 25th September, 2018. The village was visited \& enquired about the death. The death of a lady aged about 90 years was natural as informed by the villagers. However, the local media reported this death due to malaria.

The LT of CHC - Majhgawan, submitted a false report to district IDSP unit, Bareilly without preparing any blood smear from fever cases (Table 2), Moreover, when RDT kits were also not supplied to him equal to the number of tests performed by him from 2015 to 2018 (till the visit of the team). Only 100 RDT kits were supplied to him on 0905-2015 and no replenishment was done thereafter. This discrepancy in the report submitted by $\mathrm{CHC}$ to district IDSP unit was a matter of serious concern and to be looked into by district and state health authorities, in order to avoid false reporting in future. The LT was imparted malaria orientation training at State Malaria (VBD) Head quarter, Lucknow conducted from January to March, 2018. The Superintendent of $\mathrm{CHC}$ was also not serious \& vigilant for supervising the work of sub-ordinates and ability for holding the responsible position, because the technician was not performing the examination \& accordingly not reporting malaria positives in L-Form of IDSP, when this $\mathrm{CHC}$ was most affected area of the district among all the CHCs/PHCs.

The CHC- Bhamora, was the next highest fever affected $\mathrm{CHC}$, and with a population of about 2.50 lakh. This $\mathrm{CHC}$ has 174 villages, out of which 120 villages are in the grip of fever. However, no suspected death due to unidentified fever has been reported from any of the villages of this $\mathrm{CHC}$, but IDSP list has included one fever associated death from one village.

The $\mathrm{CHC}$ - Faridpur is the highest fever affected $\mathrm{CHC}$, and has about 3.00 lakh population. It was told that $\mathrm{CHC}$ area is in the grip of fever and two suspected death due to unidentified fever occurred in the villages of this $\mathrm{CHC}$ and IDSP list also includes two fever associated deaths. The death includes: (1) Mrs. Anita 22 year female w/o Mr. Rajesh R/o Rajan Paraspur expired on 27.8.208 on the way to hospital, got treatment in Ala Hazrat Hospital, Bareilly on 25-8-2018 \& left hospital on 26-8-2018, (2) Ms. Khushaboo 19 year female, D/o Mr. Onkar R/O Pitampura and expired on 25-8-2018 in Global Hospital, Bareilly. She was treated in the hospital from 23rd to 25th August, 2018 in the hospital, (3) Another death of Mr. Radhey Shyam, 35 years/male occurred on 31-8-2018 due to jaundice. He got his treatment at private hospital. It is another $\mathrm{CHC}$, where Laboratory Technician (LT), was working since 2007. He showed malaria positive blood slides and told that as per directions from higher authorities RDT kits were being used. The $\mathrm{CHC}$ was provided with two types of RDTs which are shown in Figure 4. He was asked to prepare \& examine the blood smears of RDT positive patient. The technician has got malaria orientation training at State Malaria (VBD) Head Quarter, Lucknow conducted from January to March, 2018. On scrutiny of the laboratory register, it was found that no malaria microscopy was done by LT and only RDT were being used to diagnose malaria. It was found that till $11^{\text {th }}$ Sep, 2018 only a few Plasmodium vivax cases has been detected by RDT, However, from $12^{\text {th }}$ September, 2018 
onwards, a sharp rise in malaria cases were observed (both Plasmodium falciparum \& Plasmodium vivax) as detected by RDT.

The District Male Hospital was also visited to know the status of the fever cases \& prevalence of malaria cases. One pathologist is posted at district hospital laboratory, which is also designated as the Regional diagnostic laboratory. The report of malaria case screening is given below in table-1. The RDT kits of Oscar Medicare Pvt. Ltd., New Delhi \& Malcard by J. Mitra \& Co. Pvt. Ltd., New Delhi were used in the laboratory. Some malaria positive slides were shown with gametocyte stage of Plasmodium falciparum (Pf), conforming to the presence of disease reservoir as gametocytes take more time to develop, but no other stages of Plasmodium falciparum parasite were present in the laboratory.
District IDSP unit, Bareilly was also visited to find out the communication of early warning signals of fever different $\mathrm{CHC} / \mathrm{PHC}$ of the district. The IDSP unit comprises of one Epidemiologist, one Data Manager, \& one Data entry operator. The reports of CHC-Majhgawan, provided on L-Format, did not reflect any abnormality of any disease/ fever even in the report of 24th September, 2018. No case of P.f. has been shown since 25th June, 2018 (Table 2).

The unit also provided the list of 25 fever associated deaths (17 of Majhgawan, 03 of Ramnagar, 02 of Faridpur and, one each of Bhamora, Bhojipura \& Kyara) and 21 non fever associated deaths (15 of Majhgawan, 04 of Ramnagar \& 02 of Kyara). However, none of the deaths was conformed due to malaria and no death audit was carried out by the district health authorities in view of the clinical symptoms and as per guidelines laid by NVBDCP on the prescribed format.

Table I.Report of Malaria case screening in District Male Hospital Bareilly

\begin{tabular}{|c|c|c|c|c|c|c|}
\hline \multirow{2}{*}{$\begin{array}{c}\text { S. } \\
\text { No. }\end{array}$} & \multirow{2}{*}{ Month } & \multicolumn{2}{|c|}{ Blood smears examination } & \multicolumn{2}{|c|}{ Examination by RDT } & \multirow{2}{*}{ Remarks } \\
\hline & & Number & Result & Number & Result & \\
\hline 1. & January, 2018 & 483 & All Negative & 10 & All Negative & \multirow{9}{*}{$\begin{array}{l}\text { No malaria } \\
\text { case found till } \\
\text { 25th August, } \\
2018 \text { though } \\
\text { there was } \\
\text { considerable } \\
\text { increase in fever } \\
\text { incidence during } \\
\text { July, } 2018\end{array}$} \\
\hline 2. & February, 2018 & 680 & All Negative & 18 & All Negative & \\
\hline 3. & March, 2018 & 1307 & All Negative & 68 & All Negative & \\
\hline 4. & April, 2018 & 1167 & All Negative & 44 & All Negative & \\
\hline 5. & May, 2018 & 1109 & All Negative & 59 & All Negative & \\
\hline 6. & June, 2018 & 1401 & All Negative & 50 & All Negative & \\
\hline 7. & July, 2018 & 1582 & All Negative & 61 & All Negative & \\
\hline 8. & August, 2018 & 732 & All Negative & 36 & 01 P.v. on $25-8-2018$ & \\
\hline \multirow[t]{2}{*}{9.} & September, 2018 & 401 & All Negative & 35 & All Negative & \\
\hline & Total & 8862 & All Negative & 381 & 01 P.v. on $25-8-2018$ & \\
\hline
\end{tabular}

Table 2.Reporting on Form-L of IDSP from CHC-Majhgawan in District - Bareilly

\begin{tabular}{|c|c|c|c|c|c|}
\hline \multirow[t]{2}{*}{ S. No. } & \multirow[t]{2}{*}{ Date of reporting } & \multirow{2}{*}{$\begin{array}{l}\text { Week of the report } \\
\text { (Form-L) }\end{array}$} & \multirow[t]{2}{*}{ No. of Samples tested } & \multicolumn{2}{|c|}{$\begin{array}{c}\text { Result as malaria } \\
\text { Positives }\end{array}$} \\
\hline & & & & P.v. & P.f. \\
\hline 1. & 25.06 .2018 & $18-23.06 .2018$ & 137 & 03 & 00 \\
\hline 2. & 02.07.2018 & $25-30.06 .2018$ & 139 & 03 & 00 \\
\hline 3. & 09.07.2018 & 02-07.07.2018 & 239 & 02 & 00 \\
\hline 4. & 16.07.2018 & 09-14.07.2018 & 242 & 02 & 00 \\
\hline 5. & 23.07.2018 & $16-21.07 .2018$ & 142 & 02 & 00 \\
\hline 6. & 23.07.2018 & $23-28.07 .2018$ & 108 & 00 & 00 \\
\hline 7. & 13.08 .2018 & 06-11.08.2018 & 212 & 03 & 00 \\
\hline 8. & 27.08.2018 & $20-25.08 .2018$ & 307 & 04 & 00 \\
\hline 9. & 03.09.2018 & 27.08-01.09.2018 & 311 & 03 & 00 \\
\hline 10. & 24.09 .2018 & $17-22.09 .2018$ & 322 & 03 & 00 \\
\hline
\end{tabular}


It is evident from above table that based on the reports of CHC - Majhgawan submitted to the IDSP, Bareilly, that there were only a few P. vivax cases in the $\mathrm{CHC}$ - area, yet fever incidence with mortality was not worked out properly. The Medical Superintendent has never taken pain to cross check such reports when there were high incidence of fever cases. Even the district IDSP unit did not tried to explore possibilities the cause of fever, as RDT were indiscriminately being used reflecting high P.f. malaria positivity in the district. In spite of this, the IDSP Unit did not have any Early Warning Signal (EWS) to the district health authorities regarding abnormal increase in fever cases in absence of any authentic L-form.

The District Malaria (VBD) Officer, Bareilly, sent blood smears from January to August, 2018 for cross check of malaria positives to the Additional Director, Medical Health \& Family Welfare, Bareilly (authority at Division for quality control of Blood smears) and received no discrepancy in the cross check of Blood smears (Table 3 ), The District Malaria (VBD) Officer, Bareilly, again sent 353 blood smears of Village - BehtaBujurg under CHC-Majhgawan (Worst affected $\mathrm{CHC}$ ) of the district to Additional Director, Malaria/ VBD, U.P., Jawahar Bhawan, Lucknow on 07th September, 2018. The additional Director Malaria/VBD, U.P. through his letter dated 09th September, 2018 communicated the result of blood smears (Table 4), in which only two blood smears (No. $05 \& 100$ ) were declared as positive for Plasmodium vivax malaria, which reflected that there is no grave situation as far as malaria is concerned. Thus, The District Malaria (VBD) Officer at that time, tried to find out the possible cause of fever in Majhgawan area. It was also brought to the notice that the district is conducting anti-larval spray $\&$ fogging in rural areas right from nontransmission period of the disease.

Several teams visited District Bareilly from State Head Quarter (Dte. General of Medical \& Health Services, UP) as well as from National Centre for Disease Control, GOI, Delhi during this period but none has verified death due to malaria on prescribed format of National Vector Borne Disease Control Programme.1 The team of Officers from State $\mathrm{HQ}$, Lucknow directed the district authorities to conduct malaria case screening with the help of bivalent RDT. Many teams were also deployed to screen malaria cases by RDT. It is pertinent to mention here that the RDTs are not recommended in the programme, where malaria microscopy facilities are available. The state team must have arranged Laboratory Technicians (LT) during outbreak of fever for quality diagnosis by blood smear microscopy \& prompt Radical Treatment (RT) The district has been indiscriminately using four (4) different make of antigen based bivalent RDTs supplied by various firms (Figure 4). Different types of RDTs reported different results, which might be due to their variation in their sensitivity and specificity.

Table 3.Cross check report of blood smears sent by District Malaria (VBD) Officer, Bareilly (Negative Blood Slides for malaria)

\begin{tabular}{|c|c|c|c|c|c|c|c|c|}
\hline S. No. & $\begin{array}{c}\text { No. Of } \\
\text { CHC/PHC } \\
\text { Reporting } \\
\text { Units }\end{array}$ & $\begin{array}{l}\text { Month } \\
\text { of Blood } \\
\text { smears }\end{array}$ & $\begin{array}{l}\text { Digit } \\
\text { No. }\end{array}$ & $\begin{array}{c}\text { No. of } \\
\text { Blood } \\
\text { Smears } \\
\text { Sent for } \\
\text { cross check }\end{array}$ & $\begin{array}{l}\text { To Whom } \\
\text { sent }\end{array}$ & $\begin{array}{c}\text { Handed over } \\
\text { on date }\end{array}$ & $\begin{array}{l}\text { Discrepancy } \\
\text { observed }\end{array}$ & Remarks \\
\hline 1. & 29 & JAN, 2018 & 04 & 160 & \multirow{7}{*}{$\begin{array}{l}\text { Additional } \\
\text { Director, } \\
\text { Medical, } \\
\text { Health } \\
\text { \& Family } \\
\text { Welfare, } \\
\text { Bareilly. } \\
\text { Division, } \\
\text { Bareilly }\end{array}$} & 02-02-2108 & NIL & $\begin{array}{c}\text { Majhgawan did } \\
\text { not send } B / S\end{array}$ \\
\hline 2. & 38 & MAR, 2018 & 08 & 302 & & 05-04-2108 & NIL & $\begin{array}{c}\text { Majhgawan did } \\
\text { not send B/S }\end{array}$ \\
\hline 3. & 33 & APR, 2018 & 08 & 330 & & $27-04-2108$ & NIL & $\begin{array}{c}\text { Majhgawan did } \\
\text { not send } \mathrm{B} / \mathrm{S}\end{array}$ \\
\hline 4. & 35 & MAY, 2018 & 02 & 391 & & $31-05-2108$ & NIL & $\begin{array}{c}\text { Majhgawan did } \\
\text { not send B/S }\end{array}$ \\
\hline 5. & 35 & JUN, 2018 & 07 & 418 & & $30-06-2108$ & NIL & $\begin{array}{c}\text { Majhgawan did } \\
\text { not send } B / S\end{array}$ \\
\hline 6. & 40 & JUL, 2018 & 01 & 479 & & 02-08-2108 & NIL & $\begin{array}{c}\text { Majhgawan did } \\
\text { not send B/S }\end{array}$ \\
\hline 7. & 37 & AUG, 2018 & 02 & 461 & & 04-09-2108 & NIL & $\begin{array}{c}\text { Majhgawan did } \\
\text { not send } \mathrm{B} / \mathrm{S}\end{array}$ \\
\hline Total & & & 2541 & & & NIL & & \\
\hline
\end{tabular}


The $\mathrm{CHC} / \mathrm{PHC}$ wise malaria epidemiological data of the district from 2015 to 2018 (up to August, 2018) is given in Table 5. It is evident from the table, that the malaria remained present throughout the duration but not a major public health problem, though some $\mathrm{CHCs} / \mathrm{PHCs}$ reflected multifold increase in the malaria cases. The malignant form of malaria (Plasmodium falciparum) did not exhibit its presence in the district. The In-charge District Malaria (VBD) Officer informed that all $\mathrm{CHC} / \mathrm{PHC}$ have been supplied the MF-7, MF-8 \& MF-9 registers, in order to know the focus of disease parasite in villages but they were not updated due to lack of peripheral health workers.

Since the district is invaded by several rivers like Ram Ganga (tributary of holy river Ganga) and rivers of local importance. The adequate and excess rainfall during $20181329.70 \mathrm{~mm}$ as against normal rainfall of $1000 \mathrm{~mm}$ (approximately) might have possibly created congenial conditions for development of vector population to build up density above critical level required for active transmission of malaria. The entomological survey in dusk (Indoor resting Collection) was carried out by the team in village-Dhakora and Sendhi and the vector species encountered are mentioned in Table 6.

Table 4.Cross check report of blood smears sent by District Malaria (VBD)

Officer, Bareilly (Negative Blood Slides for malaria)

\begin{tabular}{|c|c|c|c|c|c|c|c|c|}
\hline $\begin{array}{l}\text { S. } \\
\text { No. }\end{array}$ & $\begin{array}{l}\text { No. of } \\
\text { CHC/PHC } \\
\text { reporting } \\
\text { units }\end{array}$ & $\begin{array}{l}\text { Month } \\
\text { of blood } \\
\text { smears }\end{array}$ & $\begin{array}{l}\text { Digit } \\
\text { No. }\end{array}$ & $\begin{array}{l}\text { No. of blood } \\
\text { smears sent } \\
\text { for cross } \\
\text { check }\end{array}$ & $\begin{array}{l}\text { To whom } \\
\text { sent }\end{array}$ & $\begin{array}{c}\text { Handed } \\
\text { over on } \\
\text { date }\end{array}$ & $\begin{array}{c}\text { Discrepancy } \\
\text { observed }\end{array}$ & Remarks \\
\hline 1. & $\begin{array}{c}\text { CHC - } \\
\text { Majhgawan } \\
\text { (Vill. Behta } \\
\text { Bujurg) }\end{array}$ & $\begin{array}{l}\text { SEP, } \\
2018\end{array}$ & NA & 353 & $\begin{array}{l}\text { Additional } \\
\text { Director, } \\
\text { Malaria/VBD, } \\
\text { U.P., Jawahar } \\
\text { Bhawan, } \\
\text { Lucknow }\end{array}$ & 07-09-2108 & $\begin{array}{c}\text { No } \\
\text { discrepancy } \\
\text { (Test Check } \\
\text { of } B / S \text { ) }\end{array}$ & $\begin{array}{l}\text { Only two B/S } \\
\text { (N0. } 05 \& 100 \text { ) } \\
\text { Declared } \\
\text { Plasmodium } \\
\text { vivax (P.v.) } \\
\text { positive }\end{array}$ \\
\hline
\end{tabular}

Table 5.Malaria Epidemiological Situation of District Bareilly (from district health authority)

\begin{tabular}{|c|c|c|c|c|c|c|c|c|c|c|c|c|c|}
\hline \multirow{3}{*}{$\begin{array}{l}\text { S. } \\
\text { No. }\end{array}$} & \multirow{3}{*}{$\begin{array}{l}\text { Name of } \\
\mathrm{CHC} / \mathrm{PHC}\end{array}$} & \multicolumn{6}{|c|}{2015} & \multicolumn{6}{|c|}{2016} \\
\hline & & \multirow{2}{*}{$\begin{array}{l}\text { Popul- } \\
\text { ation }\end{array}$} & \multirow{2}{*}{$\begin{array}{c}\text { B/S } \\
\text { Exam. }\end{array}$} & \multicolumn{2}{|c|}{$\begin{array}{c}\text { Malaria } \\
\text { Positives }\end{array}$} & \multirow[t]{2}{*}{ SPR } & \multirow[t]{2}{*}{ API } & \multirow{2}{*}{$\begin{array}{l}\text { Popul- } \\
\text { ation }\end{array}$} & \multirow{2}{*}{$\begin{array}{c}\text { B/S } \\
\text { Exam }\end{array}$} & \multicolumn{2}{|c|}{$\begin{array}{c}\text { Malaria } \\
\text { Positives }\end{array}$} & \multirow[t]{2}{*}{ SPR } & \multirow[t]{2}{*}{ API } \\
\hline & & & & P.v. & P.f. & & & & & P.v. & P.f. & & \\
\hline 1. & Kyara & 273882 & 6487 & 5 & 0 & 0.08 & 0.018 & 276560 & 8232 & 14 & 0 & 0.17 & 0.051 \\
\hline 2. & Bhamora & 214504 & 5868 & 2 & 0 & 0.03 & 0.009 & 216649 & 7700 & 17 & 0 & 0.22 & 0.078 \\
\hline 3. & Majhgawan & 211519 & 7925 & 14 & 0 & 0.18 & 0.066 & 213634 & 6450 & 50 & 0 & 0.78 & 0.234 \\
\hline 4. & Ramnagar & 259355 & 5037 & 5 & 0 & 0.10 & 0.019 & 261951 & 7125 & 19 & 0 & 0.27 & 0.073 \\
\hline 5. & Meerganj & 177245 & 9638 & 23 & 0 & 0.24 & 0.130 & 179017 & 10444 & 45 & 0 & 0.43 & 0.251 \\
\hline 6. & Fatehganj & 227067 & 7472 & 36 & 0 & 0.48 & 0.159 & 229337 & 6402 & 38 & 0 & 0.59 & 0.166 \\
\hline 7. & Bithri & 360586 & 6433 & 1 & 0 & 0.02 & 0.003 & 364191 & 4209 & 2 & 0 & 0.05 & 0.005 \\
\hline 8. & Bhojipura & 206888 & 3222 & 13 & 0 & 0.40 & 0.063 & 208957 & 3038 & 11 & 0 & 0.36 & 0.053 \\
\hline 9. & Mundia & 226085 & 4290 & 14 & 0 & 0.33 & 0.062 & 228346 & 4810 & 24 & 0 & 0.50 & 0.105 \\
\hline 10. & Shergarh & 258733 & 6612 & 21 & 0 & 0.32 & 0.081 & 261320 & 6178 & 33 & 0 & 0.53 & 0.126 \\
\hline 11. & Baheri & 295846 & 3986 & 7 & 0 & 0.18 & 0.024 & 298804 & 4194 & 2 & 0 & 0.05 & 0.007 \\
\hline 12. & Faridpur & 257805 & 9780 & 16 & 0 & 0.16 & 0.062 & 260383 & 10916 & 46 & 0 & 0.42 & 0.177 \\
\hline 13. & Kumandanda & 183686 & 7140 & 1 & 0 & 0.01 & 0.005 & 185523 & 7683 & 5 & 0 & 0.07 & 0.027 \\
\hline 14. & Nawabganj & 302122 & 11872 & 0 & 0 & 0.00 & 0.000 & 305143 & 10457 & 11 & 0 & 0.11 & 0.036 \\
\hline 15. & Dalelnagar & 173952 & 5055 & 6 & 0 & 0.12 & 0.034 & 178583 & 6180 & 14 & 0 & 0.23 & 0.078 \\
\hline 16. & Bareilly urb & 1024012 & 7187 & 16 & 0 & 0.22 & 0.016 & 1034252 & 14777 & 64 & 0 & 0.43 & 0.062 \\
\hline Total & 4653287 & 108004 & 180 & 0 & 0.17 & 0.039 & 4702650 & 118795 & 395 & 0 & 0.33 & 0.084 & \\
\hline
\end{tabular}




\begin{tabular}{|c|c|c|c|c|c|c|c|c|c|c|c|c|c|}
\hline \multirow{3}{*}{$\begin{array}{l}\text { S. } \\
\text { No. }\end{array}$} & \multirow{3}{*}{$\begin{array}{l}\text { Name of } \\
\text { CHC/PHC }\end{array}$} & \multicolumn{6}{|c|}{2017} & \multicolumn{6}{|c|}{2018 (upto August) } \\
\hline & & \multirow{2}{*}{$\begin{array}{l}\text { Popul- } \\
\text { ation }\end{array}$} & \multirow{2}{*}{$\begin{array}{c}\text { B/S } \\
\text { Exam. }\end{array}$} & \multicolumn{2}{|c|}{$\begin{array}{l}\text { Malaria } \\
\text { Positives }\end{array}$} & \multirow[t]{2}{*}{ SPR } & \multirow[t]{2}{*}{ API } & \multirow{2}{*}{$\begin{array}{l}\text { Popul- } \\
\text { ation }\end{array}$} & \multirow{2}{*}{$\begin{array}{l}\text { B/S } \\
\text { Exam. }\end{array}$} & \multicolumn{2}{|c|}{$\begin{array}{l}\text { Malaria } \\
\text { Positives }\end{array}$} & \multirow[t]{2}{*}{ SPR } & \multirow[t]{2}{*}{ API } \\
\hline & & & & P.v. & P.f. & & & & & P.v. & P.f. & & \\
\hline 1. & ryara & $2150<0$ & 6285 & 33 & 0 & 0. & 2 & 15020 & 185 & 16 & 0 & 0. & 0.06 \\
\hline 2. & Bhamora & 218816 & 7771 & S & v & 0.11 & 0.00 & $2+0010$ & 7001 & 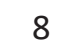 & 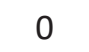 & 0.17 & 0.04 \\
\hline 3. & Majhgawan & 215770 & 8988 & D. & 0 & 0.55 & 0.20 & 215770 & 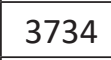 & 37 & 0 & 0.99 & 0.17 \\
\hline 4. & Ramnagar & 264570 & 9318 & 47 & 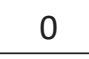 & 0.50 & 0.18 & 264 & 664 & 32 & 0 & 9 & 0.12 \\
\hline 5. & Meerganj & 180808 & 5435 & 14 & 0 & 0.26 & 0.08 & 180808 & 2612 & 7 & 0 & 0.27 & 0.04 \\
\hline 6. & Fatehganj & 231630 & 4354 & 11 & 0 & 0.25 & 0.05 & 231630 & 1739 & 15 & 0 & 0.86 & 0.06 \\
\hline 7. & thri & 367833 & 1986 & 3 & 0 & 0.15 & 0.01 & 367833 & 966 & $\perp$ & 0 & 0.10 & 0.00 \\
\hline 8. & Bhojipura & & 2 & 2 & - & & & & 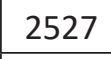 & $\epsilon$ & 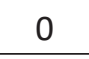 & & .03 \\
\hline 9. & & 230629 & 4264 & 1 & 0 & 0.30 & . & 230629 & 0 & 3 & 0 & & 0.01 \\
\hline 10. & Shergarh & 263933 & 3387 & 27 & 0 & 0.80 & 0.10 & 263933 & 1714 & 11 & 0 & 0.64 & 0.04 \\
\hline 11. & heri & 262986 & 3403 & 3 & 0 & 0.09 & 0.01 & 262986 & 1659 & 3 & 0 & 0.18 & 0.01 \\
\hline 12. & aridpur & 301793 & 7698 & 22 & 0 & 0.29 & 0.07 & 301793 & 3797 & 41 & 0 & 1.08 & 0.14 \\
\hline 13. & Kumandanda & 187378 & 6621 & 5 & 0 & 0.08 & 0.03 & 187378 & 2944 & J & 0 & 0.17 & 0.03 \\
\hline 14. & Nawabganj & 308196 & 7884 & 5 & 0 & 0.06 & 0.02 & 308196 & 3633 & 5 & 0 & 0.14 & 0.02 \\
\hline 15. & Dalelnagar & 180368 & 4553 & 2 & 0 & 0.04 & 0.01 & 180368 & 2574 & 2 & 0 & 0.08 & 0.01 \\
\hline 16. & Bareilly urb & 1044594 & 11849 & 35 & 0 & 0.30 & 0.03 & 1044594 & 5512 & 21 & 0 & 0.38 & 0.02 \\
\hline Total & 4752979 & 95842 & 284 & 0 & 0.30 & 0.06 & 4752979 & 47967 & 213 & 0 & 0.44 & 0.04 & \\
\hline
\end{tabular}

Table 6.Differential Vector Density in District - Bareilly, Uttar Pradesh

\begin{tabular}{|c|c|c|c|}
\hline $\begin{array}{c}\text { S. } \\
\text { No. }\end{array}$ & Name of CHC/ PHC & Majhgawan & Bhamora \\
\hline 1. & Name of Village & Dhakora & Sendhi \\
\hline 2. & Date of Collection & 26.09 .2018 & 27.09 .2018 \\
\hline 3. & Collection & Dusk & Dusk \\
\hline 4. & Time & $18.00-19.00 \mathrm{Hrs}$. & Indoor \\
\hline 5. & Site & Indoor & \multicolumn{2}{|c|}{ Density (per man hour) } \\
\hline S. & Name of Mosquito/ Vector Species & 02.00 & 05.00 \\
\hline No. & Anopheles culicifacies & 04.00 & 00 \\
\hline 1. & Anopheles annularis & 02.00 & 02.00 \\
\hline 2. & Armigeres sp. & 06.00 & 03.00 \\
\hline 3. & Culex quinquefasciatus & 04.00 & 00 \\
\hline 4. & Culex vishnuiigp. & 02.00 & \multicolumn{2}{c|}{} \\
\hline 5. & Mansonia annulifera & & \multicolumn{2}{c|}{} \\
\hline 6. & & & \\
\hline
\end{tabular}

It is apparent from Table 6, that the density of the malaria vector, Anopheles culicifacies was considerably high in CHC-Bhamora (Village-Sendhi) and above critical density required to transit malaria.

Though the District completed anti-larval spray in 1607 villages and fogging in 260 villages under campaign of prevention of communicable diseases right from nontransmission period, yet the vector density remained above critical level having no desired impact of anti-larval spray and fogging on the vector density, possibly due to the excessive rains. 


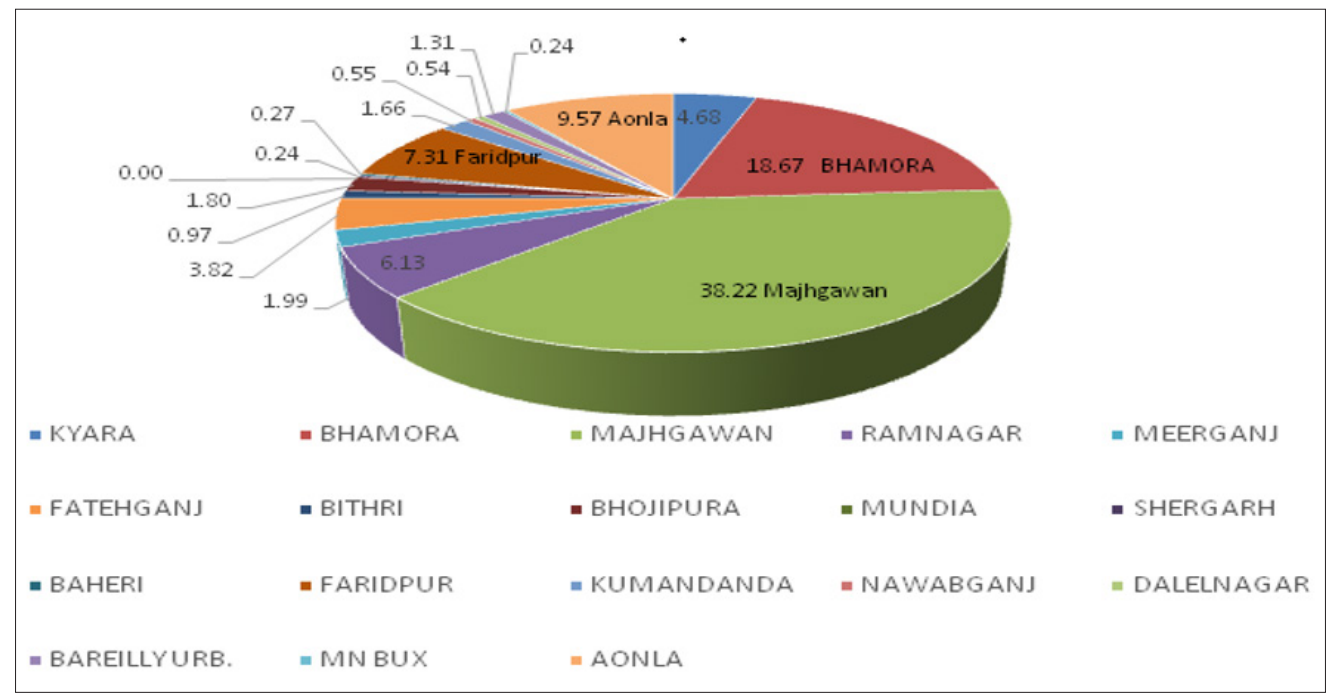

Figure 2(A).PHC wise malaria cases in Bareilly, UP

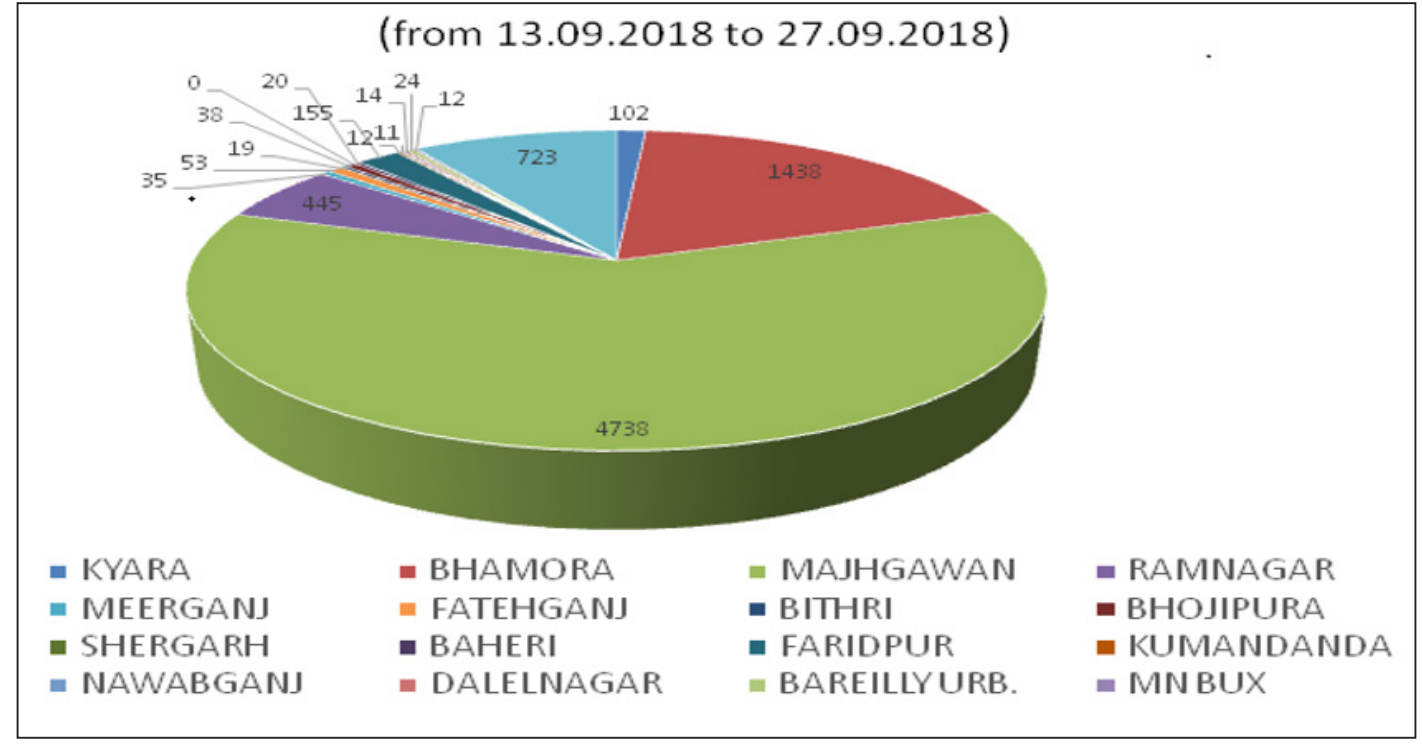

Figure 2(B).PHC wise p.f. malaria cases in Bareilly, UP

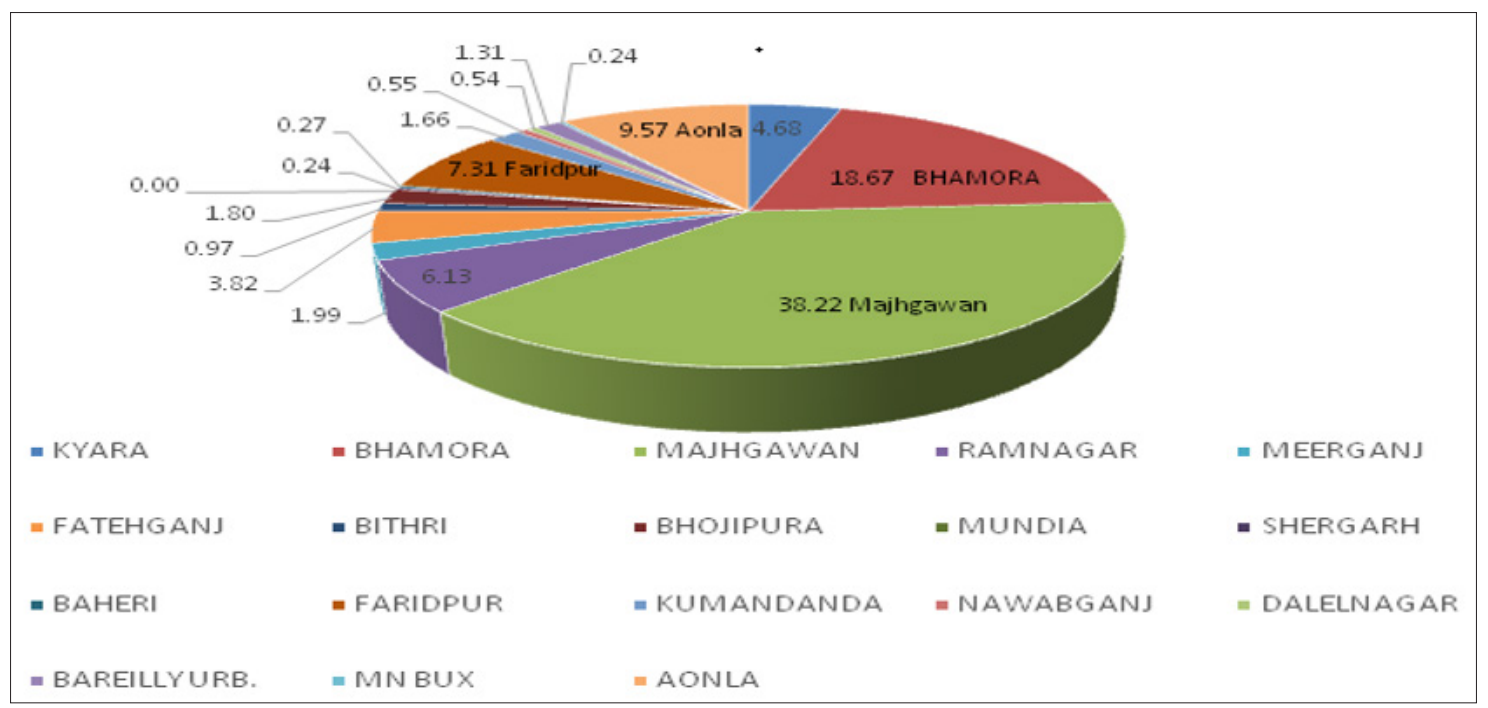

Figure 3(A).\% contribution to malaria positives 


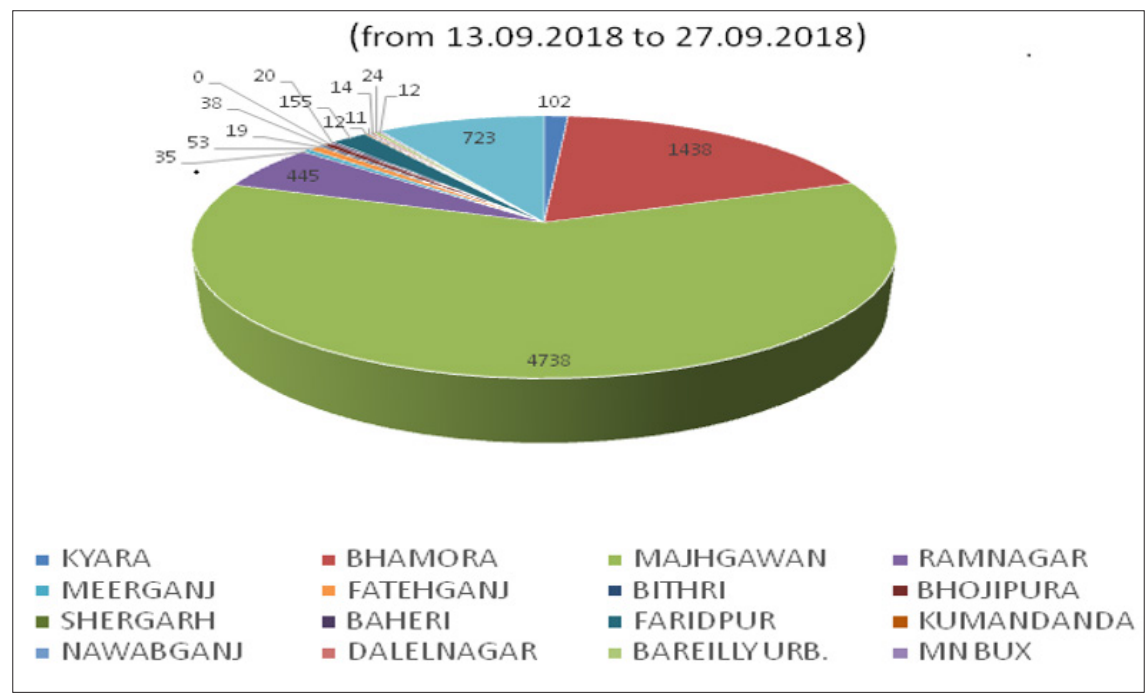

Figure 2(B).PHC wise p.f. malaria cases in Bareilly, UP

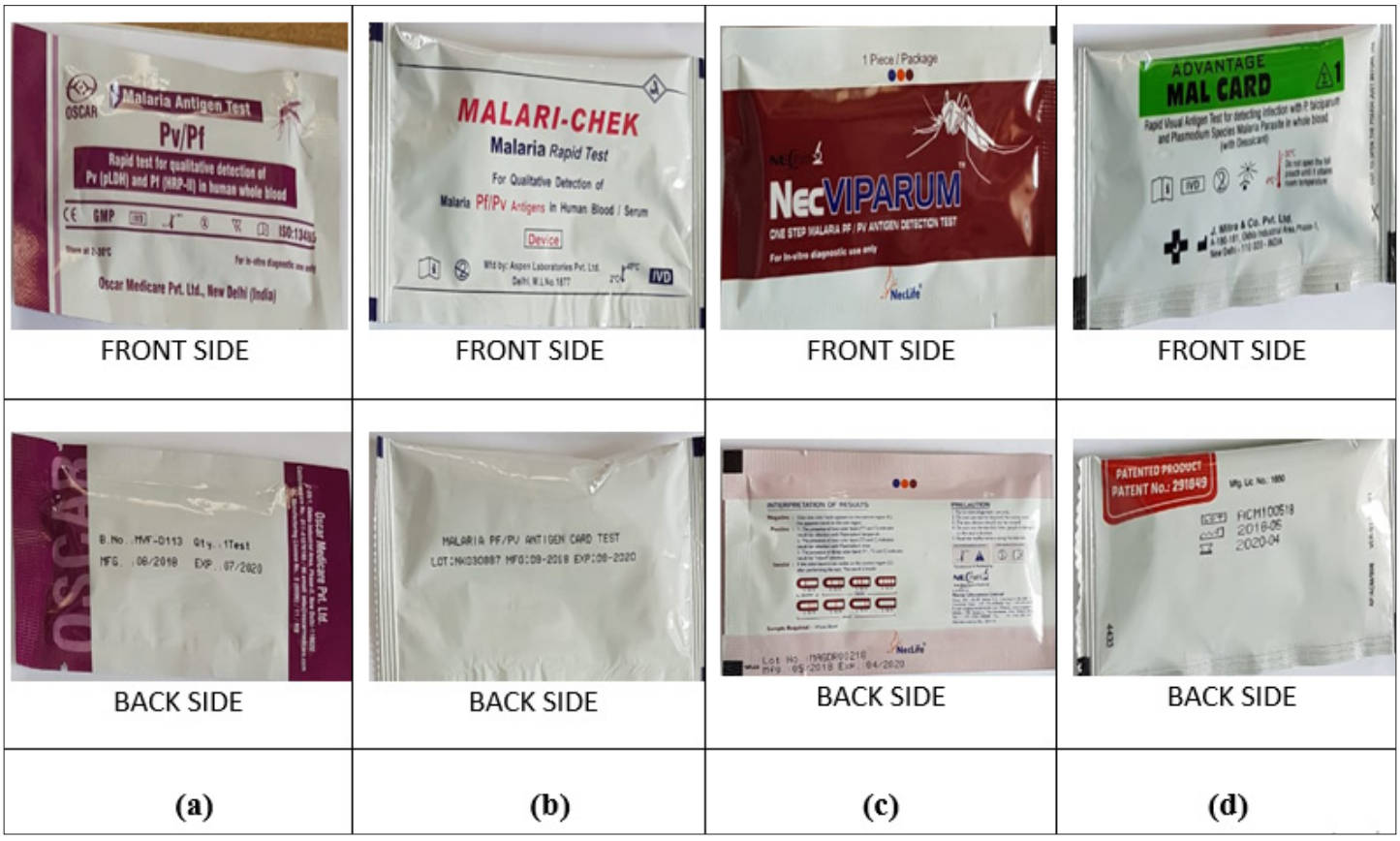

Figure 4.Different types of RDT kits used for screening of malaria cases in Bareilly districts during 2018

Table 7.Availability of Human Resource for surveillance at Village \& CHC/PHC in Bareilly, Uttar Pradesh

\begin{tabular}{|c|c|c|c|c|c|c|c|c|c|c|}
\hline \multirow{2}{*}{$\begin{array}{c}\text { S. } \\
\text { No. }\end{array}$} & $\begin{array}{c}\text { Name of CHC/ } \\
\text { PHC }\end{array}$ & \multicolumn{2}{|c|}{$\begin{array}{c}\text { Basic Health Worker } \\
\text { (Now MPW Male) }\end{array}$} & \multicolumn{2}{c|}{$\begin{array}{c}\text { Health Inspectors } \\
\text { (Now Health } \\
\text { Supervisors) }\end{array}$} & \multicolumn{3}{|c|}{$\begin{array}{c}\text { Laboratory Technicians } \\
\text { (L.Ts.) }\end{array}$} \\
\cline { 3 - 13 } & & S & P & V & S & P & V & S & P & V \\
\hline 1. & Bhamora & 10 & 02 & 08 & 06 & 02 & 04 & 01 & 00 & 01 \\
\hline 2. & Kyara & 10 & 03 & 07 & 06 & 00 & 06 & 01 & 00 & 01 \\
\hline 3. & Majhgawan & 12 & 00 & 12 & 06 & 02 & 04 & 01 & 01 & 00 \\
\hline 4. & Ramnagar & 10 & 00 & 10 & 06 & 00 & 06 & 01 & 00 & 01 \\
\hline 5. & Aonla & 10 & 00 & 10 & 00 & 00 & 00 & 01 & 00 & 01 \\
\hline 6. & Meerganj & 10 & 02 & 08 & 06 & 00 & 06 & 01 & 00 & 01 \\
\hline
\end{tabular}




\begin{tabular}{|c|c|c|c|c|c|c|c|c|c|c|}
\hline 7. & Fatehganj & 09 & 02 & 07 & 06 & 02 & 04 & 01 & 00 & 01 \\
\hline 8. & Bithiri & 15 & 00 & 15 & 06 & 01 & 05 & 01 & 00 & 01 \\
\hline 9. & Bhojipura & 10 & 01 & 09 & 06 & 01 & 05 & 01 & 00 & 01 \\
\hline 10. & Mundia & 11 & 00 & 11 & 06 & 00 & 06 & 01 & 00 & 01 \\
\hline 11. & Shergarh & 13 & 00 & 13 & 06 & 00 & 06 & 01 & 00 & 01 \\
\hline 12. & Baheri & 16 & 00 & 16 & 08 & 00 & 08 & 01 & 00 & 01 \\
\hline 13. & Faridpur & 12 & 00 & 12 & 06 & 00 & 06 & 01 & 01 & 00 \\
\hline 14. & Kuwandanda & 12 & 00 & 12 & 06 & 01 & 05 & 01 & 00 & 01 \\
\hline 15. & Nawabganj & 15 & 00 & 15 & 06 & 01 & 05 & 01 & 00 & 01 \\
\hline 16. & Dalel Nagar & 16 & 00 & 16 & 08 & 00 & 08 & 01 & 00 & 01 \\
\hline 17. & Distt.HQ & 00 & 00 & 00 & 00 & 00 & 00 & 01 & 01 & 00 \\
\hline Total & 181 & 10 & 171 & 94 & 10 & 84 & 17 & 03 & 14 & \\
\hline Vacant Posts (\%) & 94.48 & 89.36 & 82.35 & & & & & & & \\
\hline
\end{tabular}

$\mathrm{S}=$ Sanctioned, $\mathrm{P}=$ Posted, $\mathrm{V}=$ Vacant.

The district and $\mathrm{CHC} / \mathrm{PHC}$ authorities were asked to ensure preparation and examination of blood smears from all fever cases declared positive for P.f. \& mixed cases by the RDTs for verification of the parasite prevalence $\&$ its potential role in the occurrence of the wide spread fever in the area. When RDTs are reflecting P.f. presence, there are many more chances of getting P.f. in blood smears. Some of the deaths occurred during the current fever outbreak, though not verified due to malaria, and may be attributed to the malaria keeping in view the prevalence of P.f. malaria cases detected through RDT, which reflects its presence. Treating malaria at an individual level is very simple; but it is very complex, when undertaken as a programme, because the disease transmission is governed by many biotic and a biotic factors related to the parasite, vector and host behavior in different environmental conditions. Chand G, et al. ${ }^{4}$ attributed the malaria outbreak in Madhya Pradesh due to prevalence of rice cultivating ecosystem without any intervention measure like insecticidal spray, though qualified for undertaking intervention measures according to NVBDCP guidelines. Josh PL, et al. ${ }^{5}$ attributed the malaria outbreak in Uttar Pradesh due to neglected surveillance. The present fever outbreak cannot be denied to be associated with malaria. The outbreak of the fever may be attributed to negligent disease \& vector surveillance as well as poor quality of malaria microscopy. In absence of technical staff related to surveillance and diagnosis, as is evident from the Table 7, consequently, early detection \& prompt treatment (EDPT) was severely affected and delayed, leading to the present outbreak.

On analyzing the data and assessing the situation in the district, the district authorities were asked to undertake space spray with pyrethrum ( $0.1 \%$ solution) to interrupt the transmission of malaria by killing the infected mosquito population followed by Indoor Residual spray with DDT50\% wdp the insecticide available in the state, for which the State VBD Programme Officer was requested to divert the DDT 50\% wdp from other district. According the DDT 50\% $w d p$ was diverted to the district without any delay. The district authorities started space spray with the pyrethrum ( $0.1 \%$ solution) in the highly affected 21 villages in CHCMajhgawan, 11 villages of CHC-Bhamora, and CHC-Faridpur.

On the basis of the observations made during the course of the investigations, several gaps and lacunae were observed which includes: (a) The fever cases with standard case definitions based on laboratory diagnosis (microscopic) should have been given radical treatment \& compliance of RT should have been ensured, (b) Blood smears should be collected simultaneously from all patient showing positivity by RDT kit in order to establish the specificity and sensitivity of these kits, (c) The quality control of laboratory diagnosis (microscopic) should be ensured at peripheral level, and (d) The Zonal entomological team based at Bareilly should be strengthened in terms of manpower \& Infrastructure in order to conduct regular entomological surveillance to keep vigil on vector density \& to suggest proper vector control measures. The state VBD programme authorities are advised to review the availability of technical staff related to surveillance and diagnosis of fever/malaria in other districts as well, in order to prevent any such outbreak or epidemic in future.

\section{Acknowledgement}

The authors are thankful to Dr. V.K. Shukla, Chief Medical Officer and Dr. D. R. Singh, District Malaria (VBD) Officer, Bareilly for their support and help extended during the field visits to the affected $\mathrm{CHC} / \mathrm{PHC}$ and villages during the investigation period. 


\section{Conflict of Interest: None}

\section{References}

1. Operational Manual for Malaria Action Programme National Malaria Eradication Programme. 1995; 1-223.

2. Lal S, Dhillon GPS, Sonal GS et al. Country Scenario Malaria and its control in India. J Commun Dis 1998.

3. Dhingra N, Dhillon GPS, Lal S. Process Indicators for Malaria Control. J Commun Dis 1998; 30(3): 209-228.

4. Chand G, Roy SK, Tiwary RS. Malaria epidemic in Lamta $\mathrm{PHC}$ of Balaghat district $-\mathrm{A}$ rice cultivating ecosystem. J Commun Dis 1997; 29(2): 179-181.

5. Sharma RS, Lal S, Sharma SN et al. Malaria outbreak in Mewat region Gurgaon district of Haryana State. J Commun Dis 1997; 29(3): 307-8.

6. Joshi PL, Chandra R, Bhattacharya M. An outbreak of Malaria in district Mahrajganj-An outcome of neglected surveillance. J Commun Dis 1999; 31(1): 63-5.

7. National Framework for Malaria Elimination in India (2016-2030). National Vector Borne Disease Control Programme, Directorate General of Health Services, Ministry of Health \& Family Welfare, Government of India, Delhi. 2016; 43.

8. National Strategic Plan for Malaria Elimination in India (2017-2022). National Vector Borne Disease Control Programme, Directorate General of Health Services, Ministry of Health \& Family Welfare, Government of India, Delhi. 2017; 100. 